\title{
Towards a Theory of Arbitrary Law-making in Migration Policy
}

\author{
Patricia Mindus
}

Uppsala University, patricia.mindus@uppsalaforum.uu.se

DOI: http://dx.doi.org/10.5324/eip.v14i2.3712

(cc) BY
Attribution 4.0 International License, which permits unrestricted use, distribution, and
reproduction in any medium, provided the original author and source are credited.

The article considers what arbitrary law-making is and what may count as arbitrary law-making in the field of migration policy. It contributes to the discussion of arbitrary law-making in relation to migration policy in two ways. First, it offers an analysis of arbitrariness, pointing out that rhetorical definitions abound - perhaps not surprisingly, given that migration is a highly-contested policy area - and argues for why transposing a conception developed in ethical theory to the law has high theoretical costs. An alternative conception is described and found to be better equipped to deal with arbitrary law-making in migration policy. It is argued that if we want to understand how arbitrariness plays out in the field of migration law which is necessary to find ways to hinder its spread by the adoption of specific lawmaking practices - we first need to distinguish arbitrariness from legitimate choices of legislators. Secondly, a typology of forms of arbitrariness is fleshed out in relation to contemporary migration policy. The policy area is here broadly construed to include not only naturalisation processes, but also migration, asylum and refugee policies and more generally border control. The examples are taken from a broad selection of countries. They have been chosen for illustrative purposes only.

Keywords: arbitrariness, discretion, arbitrary power, forms of arbitrary power, borders, migration policy, citizenship policy

Miserable is the slavery of that people among whom the law is either unsettled or unknown.

Jeremy Bentham (1838-1843, 235)

The positive element in laws concerns only their form of publicity and authority (...). Their content per se may be reasonable - or it may be unreasonable and wrong. But when right (...) is developed in detail, this analysis, because of the finitude of its materials, falls into the falsely infinite progress: the final definiteness, which is absolutely essential (...), can in this sphere of finitude be attained only in a way that savours of contingency and arbitrariness. Thus whether three years, ten thalers, or only (...) $24 / 5$ years (...) be the right and just thing, can by no means be decided on intelligible principles - and yet it should be decided. Hence, though of course only at the 
final points of deciding (...) the 'positive' principle naturally enters law as contingency and arbitrariness. This happens and has from of old happened in all legislations: the only thing is clearly to be aware of it, and not be misled by the talk (...) as if the ideal of law were, or could be, to be, at every point, determined through reason or legal intelligence, on purely reasonable and intelligent grounds. It is a futile perfectionism to have such expectations.

Hegel $(2010, \S 529)$

\section{Introduction ${ }^{1}$}

Arbitrariness is detrimental to the legitimacy of any rule in a deep and decisive way. Yet, it is poorly understood in relation to citizenship and migration policy. This is regrettable because this policy area offers some interesting testing ground for thinking about what arbitrary law-making is and what may count as arbitrary lawmaking. Migration law warrants greater interest among legal theorists. While plenty of legal theorists engage with constitutional law, EU law, international law, WTO law, HR law and more, few legal and practical philosophers engage with migration law - an area of law that has until quite recently been marked by low status even among black-letter lawyers, notwithstanding its connection to the very lucrative area of international private law. The policy field is too often relegated to the obscure technicalities of administrative law and public security concerns, where sovereignty claims have a long-standing tradition of not needing to provide any reasons, let alone good ones. The State's 'sovereign right to exclude'2 is not seriously contested in contemporary international law. This makes migration law an interesting case to study for scholars interested in understanding how the lack of legal certainty plays out in arbitrary practices. By viewing citizenship and migration policies from the perspective of the rule of law, arbitrary law-making emerges in a new light.

The state of our current knowledge about arbitrary law-making is regrettable not only in reference to law and legal theory, but also in terms of practical philosophy and applied ethics. It is well-known that migration provides an opportunity to recast the opposition between universalism and particularism: Debates on open vs. closed borders (Carens 1987; Bauböck 1994), on global justice (Jones 2001; Juss 2006) and other topics have brought this contrast to the fore, starting with Walzer's Spheres of Justice (1983) that inaugurated a prolific string of studies on the distribution of goods within systems with open borders. Many researchers have tried to reconstruct the vast and complex debate on migration and to bring some clarity to the many conflicting positions on migration ethics (Nardin, Mapel 1992; Goodin 1992; Fine \& Ypi 2016). This paper does not attempt to add to this literature, but has another starting point. The great variety of theoretical and regulatory orientations in this literature share the - perhaps surprising - fact that little attention has been directed towards what arbitrariness is and how it plays out in the setting where these norms come to be, namely migration law. What does arbitrariness mean in this context? What counts as arbitrary law-making when we are discussing migration policy? What distinguishes discretion from arbitrary rule in this context? And foremost, by virtue of what may we call out a practice or a norm as being arbitrary without giving expression to personal predilections? 
Law-making is most often said to be 'arbitrary' in a rhetorical way, as a way to delegitimise the theoretical or political opponent, thus making the stigma of arbitrary law-making coincide with what the author dislikes or finds incompatible with his/her moral intuitions or with the ethical principles assumed. The scarcity of literature on the concept of arbitrary law-making, as compared for instance to that on the rule of law, may be due to its axiologically negative undertones. Perhaps it is taken to be a term more suitable for political debate than for scientific inquiry? Yet, establishing the non-arbitrariness of a rule or a practice is particularly relevant in democratic states where the legal order is grounded on the ideal of the rule of law, and political legitimacy depends on the rejection of capricious, unpredictable and unreasonable laws (Rothstein 2011). This paper thus builds on the assumption that much is to be gained from better understanding what may count as arbitrary law-making.

The paper is organised as follows. Section 2 introduces a semantic analysis of arbitrariness in relation to authority. A finding is that arbitrariness, once connected to collective agency, loses the axiologically positive and/or neutral undertones it has in discussions of free will. In Section 3, a distinction is made between legal and philosophical understandings of arbitrariness. The philosophical understanding is found to be unfit for use within the legal setting for a variety of reasons. These reasons for rejecting the more commonly employed conception of arbitrariness are important to justify adopting the alternative conception of arbitrariness that the rest of the paper builds on. In Section 4 a triadic typology of forms of arbitrariness, based on the legal understanding of arbitrariness, is introduced. In Section 5, a first form of arbitrary law-making is illustrated in relation to contemporary migration policy, where arbitrariness consists in a breach of legality. In particular, reference is made to the notion of 'illegal migrants'. In Section 6, a second form of arbitrary law-making is illustrated on the backdrop of migration policy, where arbitrariness equals irrationality in the sense of inconsistency between means and end. The focus is on Safe Third Country Rules and particularly strict deadlines for filing certain applications. In Section 7, a third form of arbitrary law-making is illustrated with examples taken from migration policy, where arbitrariness is substantiated by forms of discrimination. In particular, attention is directed to provisions relating to asylum law.

\section{Arbitrariness in Relation to Individual and Collective Agency}

A word on the nature of arbitrary rule is needed. "Arbitrary" - from the Latin word arbiter - is an adjective that qualifies an autonomous judgment or a free act. Since the Middle Ages, the debate on free will has pitted those who defend the libero arbitrio against supporters of the theory of predestination, the servo arbitrio; this is in modern terms a deterministic account of will formation. Notice that the notion of arbitrariness, once connected to agency, has axiologically positive and/or neutral undertones in discussions of free will. However, this radically changes when the term refers to a relationship between two or more people. Indeed, the axiologically positive and/or neutral undertones associated with the term when employed in relation to individual agency change when the term is used to refer to forms of agency involving more than one individual or concerning collective agency. Indeed, talk of an 'arbitrary authority' is indeed axiologically charged in negative terms. 
When referring to the relationships between several persons, the term becomes associated with notions quite different from that of free will: the lack of reasongiving, legitimacy, well-foundedness of the authority or institution or rule, or a decision marked by 'arbitrariness'. In the classical Satire VI, Juvenal tells the story of a Roman matron who condemns one of her slaves to death without any reason: "'Crucify that slave!' says the wife. 'But what crime worthy of death has he committed?' asks the husband (...); 'This is my will and my command: let my will be the voucher for the deed." This is a paradigmatic example of what we call an arbitrary decision imposed by one person on another.

Notice that this idea of arbitrariness as the illegitimate rule of one over another recurs in the contemporary republican debate on domination. According to Frank Lovett and Philip Pettit, a free person is "one who does not live under the arbitrary will or domination of others" (Lovett \& Pettit 2009, 12). ${ }^{3}$ Locke already used "arbitrary" to define slavery as the condition under which a person is not only subjected to another's will but to a will that is "inconstant, uncertain, unknown" (Locke 1982, 242). The arbitrary will refers, in this context, to judgments based on private interests, desires, moods or whims. The ban of arbitrary detention - the fundamental right of the Habeas Corpus tradition - embodies this freedom from others' whimsical decisions and shows the importance of the notion of arbitrariness in the constitutional tradition. We can thus say that the expression "arbitrary power" typically refers to an authority which is free to act following nothing but its own initiative, without considering any limits or constraints. To use Montesquieu's classical phrasing in De l'esprit des lois: "It has eternally been observed that any man who has power is led to abuse it; he continues until he finds limits" (Montesquieu 1989, 155).

It is in connection to power or authority, not to mere capacity of will formation, that we need to understand Tim Endicott's claim that "in the special sense in which arbitrariness is a departure from the rule of law, a decision is arbitrary whenever the law itself ought to demand a justification other than the fact that the decision maker made it, and there is no such justification" (Endicott 2014, 18). So, in the semantic area where 'arbitrary' does not qualify mere will formation of individual agency, but rather refers to an authority with the power to make decisions valid for others - typically, erga omnes validity referring to forms of collective agency - we find the pair of conceptual opposites arbitrary power versus limited power. It is also clear that this pair of opposites is based on the Montesquieuvian intuition that arbitrariness is power that exceeds the limits it normally stands under. This paper builds on this pair of conceptual opposites in order to distinguish between different understandings of what may count as arbitrary law-making.

The change in axiological undertones according to whether 'arbitrary' qualifies individual or collective agency helps to explain the impression that, in relation to migration policy, the appeal to 'arbitrariness' seems to be a mere rhetorical tool for stigmatisation. Citizenship is a 'core sovereignty' area and migration a highlycontested political issue (Fine \& Ypi 2016; Mindus 2017, 2019). Perhaps it is then not surprising that rhetorical definitions of arbitrariness abound in the literature on migration policy. A definition counts as rhetorical when 'arbitrary' indicates that which is disliked, regardless of how agreeable the potential underlying reasons for this attitude may be. Such uses of arbitrariness as a rhetorical tool for stigmatisation 
that are recurrent in all political contexts, are also quite unhelpful for understanding what may count as arbitrary law-making.

Once we clarify that - in the semantic field where the reference is to collective decision-making and not simply individual will formation - it makes sense to oppose 'arbitrary' and 'limited', let us ask what it means for a decision of a collective agent to be 'arbitrary'? The next section illustrates different interpretations thereof that are critical to distinguish between the philosophical and the legal understandings of arbitrariness.

\section{Arbitrary, Contingent, Discretionary: Some Basic Distinctions}

\subsection{Arbitrariness versus Contingency: A Philosophical Legacy}

Putting aside the generic rhetorical use of 'arbitrariness' as a normatively loaded term - the use of which aims to stigmatise a decision, rule or authority, where arbitrary basically means something pejorative - we find that a more refined way of employing the term recurs in the work of many contemporary analytical philosophers. In contemporary philosophy, a technical-analytical understanding is attributed to 'arbitrary'. The term then refers to one of two possible meanings: $(i)$ "morally arbitrary" as a synonym of 'unjustified' or (ii) a series of contingent elements. This latter meaning is the specific sense that contingency has acquired in the debate on moral luck initiated by Bernard Williams. In analytical philosophy and normative ethics associated with this tradition since then, 'arbitrary' means contingent or non-necessary. Both of these meanings are problematic when discussing the law in general and migration law in particular. When referring to collective decisions and rules with erga omnes validity, as in the case of the law, 'arbitrary' typically does not indicate an exercise of power that is morally unjustified or dependent on contingent factors beyond the control of the individual. This creates some confusion, and it is thus important to recognise that a philosophical understanding of arbitrariness exists that differs from the legal understanding.

When we talk about collective decisions and rules with erga omnes validity, not much is gained by adopting an understanding of the first kind: (i) falls back on the equally vague notion of moral justification that, in itself, is problematic to use because (1) there are many competing moral theories; (2) we disagree over how to best measure the value of different theories and (3) we are discussing the law, not morals. The law may have legal validity that does not coincide with moral validity (otherwise, there could be no immoral laws). While there is little dispute about the fact that not all laws are morally justified, few people are committed to the view that moral invalidity brings about legal invalidity. If we want to maintain a distinction between moral and legal validity, it is important not to collapse arbitrariness into a lack of moral justification: such a conceptual collapse of genres would come only at the risk of ignoring the difference between ethics and law, too high a theoretical prize to pay.

In the second sense (ii), arbitrary means contingent, and this meaning is also problematic when discussing law-making for different reasons. In a famous 1981 essay, Williams states that "nothing that is produced by contingencies, whether happy or unhappy, can be the subject of moral considerations" (Williams 1981, 20). According to this perspective, "contingent and fortuitous issues should not be 
considered in moral evaluations" (Nine 2012, 8). On Williams' understanding of arbitrary, that which is contingent is thus not the proper subject of moral considerations. Yet, this does not imply that the fortuitous dimension of our lives may not be said to have legal or political relevance. Many legally and politically relevant facts are not morally relevant in the abovementioned sense. So, the fact that contingent matters ought not count in normative ethics says little about whether they should count in law.

Now, the technical-philosophical understanding of arbitrariness prevails in the debates on migration, open borders and global justice. Discussions on the arbitrary nature of migration law typically use a notion of arbitrariness construed as synonymous with 'lack of moral justification.' This notion comes from ethical theory and more specifically from the work of Thomas Nagel and Bernard Williams. If, for example, we look at Cara Nine's work, the reflection on the arbitrariness of territorial borders is based on the assumption that "what is available - that is, capable of being distributed starting from principles of justice - must not be influenced by morally arbitrary considerations" (Nine 2012, 5). Similarly, Margaret Moore laments the "ad hoc reasoning" that afflicts reasoning about whom territories belong to and argues for a justification in terms of the "moral value of self-determination" (Moore 2017). Paulina Ochoa Espejo has defended the need for robust moral justification of one's connection to a place: ius situs is cast as "a distinct level of morality, which means that it is derived from the basic principles of morality" (Ochoa Espejo 2016, 79; 2020).

The notion of 'morally arbitrary' here indicates a series of contingent elements, in the specific sense that the term has acquired in the ethical debate on moral luck. Given the backdrop of this understanding, it becomes evident why being born in one country rather than another would be arbitrary, as argued by Ayalet Shachar in The Birth Right Lottery (2009): The place of our birth is 'beyond our control', to use Nagel's idea of contingency, an idea of contingency cast in metaphysical-causal terms. ${ }^{4}$ It is equally clear why the way borders are drawn would be arbitrary, as shown by Charles Beitz in Political Theory and International Relations (1979): Borders are the result of historical 'contingencies', as Williams would have pointed out in line with his genealogical understanding of contingency.

Leaving aside that within a strictly legal setting, the assumption - that arbitrariness equates to lack of moral justification - itself corresponds to a substantial and rather problematic legal theoretical commitment to non-positivism (Mindus \& Spaak 2021), the high theoretical costs of transposing a notion developed in ethical theory to the law is undisputable. One such cost is the unfamiliarity of the lexis. In lawyer lingo, arbitrary is not in opposition to what is morally justified but rather to discretion. The distinction between arbitrariness and discretion is grounded on a conceptual pair of opposites - "arbitrary" versus "limited" - which is different from the conceptual pair of opposites - "arbitrary" as opposed to "morally unjustified" and to "contingent" - that grounded the aforementioned philosophical understanding.

Instead of transliterating notions developed in a quite different scientific context (ethical theory) and for quite divergent scientific purposes (rendering of the problem of moral luck), what follows will build on the legal understanding of arbitrariness. 


\subsection{Arbitrariness versus Discretion: A Legal Legacy}

Much has been said by legal theoreticians and administrative lawyers - particularly within the civil law tradition - about what characterises arbitrariness and how to distinguish it from discretion (e.g. Leibholz 1959, García de Enterría 1991, Igartua 1996, de Laubadère 1996, Ramón Fernández 1998, Mesquina 2003, Rebelo de Sousa and Salgado de Matos 2008, Ramón Fernández 2008, 2016). A commonly accepted reading is that arbitrary in the legal context means the opposite of discretion (Lifante Vidal 2003). When granted to administrative authorities by law, discretion involves the possibility of selecting between different yet equally legitimate solutions. This implies that a significant amount of power resides in deciding a particular case (Ragonesi 1996, 225). ${ }^{5}$ While discretion is a legally legitimate act of power, arbitrary exercises of power are not. On this reading, discretion is grounded in a norm of competence (e.g. Spaak 2003); for instance, the law gives a judge the competence to make a choice that falls within a predefined (discretionary) range, much in the same way that constitutional law commands legislators to make choices that fall within the predefined range of the constitution and bans acts in breach of it. An act that may be said to qualify as arbitrary, on the other hand, is not grounded in a norm of competence; rather, the opposite holds. An arbitrary act is arbitrary because it goes beyond the law. This is in line with the claim that arbitrary power is unbound or unchecked power or an exercise of power beyond the limits set by the law. Authority can therefore be understood to have a discretional nature if it acts freely within the boundaries defined by law (Hawkins 2002), and to have an arbitrary nature if it acts beyond the same boundaries. Arbitrariness is the expression of unlimited power, such as the power of the sovereign state in its dealings with those whom it does not believe it has reason to respond to.

The legal understanding of arbitrariness has a series of advantages in this context. First, it is not committed to any particular arrangement between normative systems, and in particular between ethics and the law. Secondly, it is not affected by there being several competing ethical theories. It is useful to reclaim this legal understanding of arbitrariness; it helps to distinguish between various forms of arbitrary exercise of power.

Now, a difficulty for the legal understanding of arbitrariness is that the limit between a discretionary and an arbitrary practice depends on many factors, some of which may be contextual. In other words, the distinction is conceptually clear as far as its intension is concerned, but it is not always clear as far as its extensional uses are concerned.

The law has furthermore elaborated a range of instruments to seek to establish whether a given act counts as an expression of discretion or arbitrariness. The socalled 'quality of law' or 'quality of legislation' literature tracks these instruments, now also in relation to migration law (Mindus \& Prats 2020). Techniques are available to prevent discretion from turning into arbitrariness. For instance, legislative drafting tools that may be used by law-makers to achieve this purpose include avoiding imprecise or vague terminology, using discretion only when strictly necessary, making clear in the law the precise conditions under which discretion may be used and avoiding the use of discretion as a principle. When fundamental individual rights are at stake, the law needs to reduce discretion to the bare minimum. Attention to language also becomes necessary where the clear 
identification of discretionary powers in the law is concerned. Using expressions that are as clear as possible regarding discretionary powers helps to clarify the conditions under which discretion may be employed (e.g. terms such as may, shall, has the right to or shall only be refused if). These tools are not a bulletproof guarantee that arbitrariness will be avoided. But they do provide some necessary conditions for the using and applying discretionary powers in ways that are respectful of the aim to distinguish discretion from arbitrariness in the design of the laws.

Among the few scholars who have made an effort to articulate the meaning of 'arbitrariness' in procedural terms relative to withdrawal of citizenship, mention should be made of De Groot and Vink who make a clear effort to explain what the prohibition on arbitrary withdrawal means in the law (De Groot and Vink 2014; ILEC 2015): Revocation procedures might be considered arbitrary if they are not based in law, extend loss retroactively, are based on provisions that are not easily accessible, comprehensible and predictable, are based on discriminatory provisions, are unchallengeable in court or create statelessness where no fraud is detected. They also insist that proportionality is paramount to the effect that withdrawal pursuant to condemnation for minor offences would fall into arbitrary loss, as would decisions of withdrawal that do not take account of people's situation, culpability, the circumstances of the acts, and the impact on their and their family's right to reside in the country. It is clear from this example relating to denationalisation that if one wants to explore how arbitrariness in the field of migration law is hindered or fostered by adopting specific law-making practices, first being able to distinguish arbitrariness from discretionary practices is paramount. Arbitrariness, in contrast to discretion, undermines legitimacy in a deep way that is not easy to remedy.

Indeed, arbitrariness erodes trust in the law (Gkouvas and Mindus 2020). It is well known that frequent exposure to rules perceived to be unintelligible, arbitrary or simply unwarranted results in signs of distress and mistrust of organisations and institutional staff in authoritative positions. Eroding trust in the law is an extremely high price to pay for suboptimal design choices in the law-making area. At the same time, it has been observed that discretionary power is typically paired with high levels of trust. As Scott Shapiro remarks in his work on the economy of trust, "the more trustworthy a person is judged to be, the more interpretive discretion he or she is accorded; conversely, the less trusted one is in other parts of legal life, the less discretion one is allowed" (Shapiro 2011, 331). Therefore, from this perspective, trust appears to be the key value at stake. The lack of discretionary power attributed to determinate players within migration law - to undocumented migrants, for instance - might be a sign of the fact that the law casts these players as less trustworthy agents, in itself an aspect deserving debate.

\section{A Triadic Typology of Forms of Arbitrariness}

On the basis of an understanding of arbitrariness suited to discussing legal matters, we have now sought to establish the difference between discretionary and arbitrary law-making. The distinction depends on whether the exercise of power that leads to a determinate outcome - a rule or decision - occurs within or beyond the limits 
set by the law. We still need to stress that a given power may exceed the limits of the law in a variety of ways.

Building on the work of Cuono (2018), who has shown the purposefulness, in relation to legislation, of distinguishing between three ways in which an authority can be said to exercise arbitrary power, it is possible to present a typology of arbitrary law-making. Arbitrary law-making may be said to include three different types of law-making, i.e. law-making that is: (a) illegal, at odds with a defined legal rule, often at a superior level; (b) irrational, irreconcilable with the standards of logic or the means-to-an-end calculus; or (c) discriminatory, based on categories that in themselves challenge the basic equality principle of legal systems. ${ }^{6}$ These types of arbitrary law-making are distinguished below and briefly outlined, against the backdrop of some classical topoi in the history of practical philosophy. The purpose of these references is not genealogic or historical, but explanatory.

Two caveats are required at this point. First, the fact that the aforementioned types are different means that they call for different solutions. Catch-all solutions ought therefore to be rejected. The kind of arbitrary law-making involved in (a), (b) and (c) can be more or less problematic and requires different argumentative strategies and legal-political tools to be resolved. Distinguishing between (a) illegal practices, (b) irrational policies and (c) discriminatory statuses is helpful in order to clarify and differentiate among forms of abuse, and to be able to distinguish between various forms of arbitrary law-making. Yet, it is necessary to stress that, if faced with an illegal practice, it needs to be overcome by enforcing a higher standing rule (e.g. through constitutional review); it cannot be overcome by argumentation or scientific-technical inquiry (which may, however, help to hinder or impede irrational policies that are fundamentally ill-conceived by the lawmakers), nor can illegal practices be defused by further political and/or cultural debate (which can, however, be useful to fight lawmakers' crafting of discriminatory statuses). Nonetheless, whether the intervention of constitutional judges would be the appropriate response to tackle forms of irrational policies, for example, would depend on many empirical factors, including the kind of constitutional review (ex ante or ex post review), the authority of the court, nomination practices, and finally, the complexity of the choice lawmakers were called on to make in the first place. The higher the complexity, the lower the possibility that the choice appears irrational to all actors involved.

The second caveat is that the typology presented in this paper does not address the problem of whether, and under which conditions, one type of arbitrary lawmaking is to be considered somehow conceptually or causally prior to another or whether we ought to prefer one type over another; nor whether such judgements are meaningful in the first place.

The first type of arbitrary law-making is the exercise of a power that exceeds the limits set by law by opting for an illegal choice. Illegal here means at odds with valid law, often of a superior level. This is a rather common and generic way to speak about 'arbitrary law-making', where "arbitrary" is synonymous with invalid.

Generally, arbitrary law-making of this first type (i.e. illegal practices) finds its most classical topos in the Platonic opposition between the empire of law and that of men (Statesman, 294a); or, in the terms of the U.S. Supreme Court, "a government of laws and not of men" (Marbury vs. Madison 1803, 5 US 137, 163). 
The idea that arbitrary law-making could indicate illegal acts may result from the legal understanding of arbitrariness employed here, which is based on the conceptual pair of opposites arbitrary versus limited, giving the impression that arbitrary always indicates something that falls 'outside the law'. Once we take into consideration the various subtypes of the general category of illegality, we find that the impression is more nuanced. These subtypes are relevant here.

The acts of an arbitrary authority, in the sense employed above, may refer either to its behaviour (practices in the strict sense) or to the norms, rules and decisions it issues (normative practice in the broad sense). Both kinds of act challenge (at least one of) the two main variants of the rule of law: (i), government by law, i.e. gubernaculum sub lege (GSL) and (ii) government through laws, i.e. gubernaculum per leges (GPL). GSL and GPL may be said to constitute, respectively, two subtypes of the first type of arbitrary law-making.

GSL is the doctrine that calls for political authority to respect higher norms. In contemporary constitutional democracy, the legislative branch of government ought to produce law that respects not only formal constitutional procedures but also substantial constitutional limits as to the content of the law, such as respect of fundamental rights (gubernaculum sub iuribus). GPL calls for political authority to express itself in the form of general and abstract rules. Today, this is what we refer to when, for instance, we claim that parliaments should respect values such as legal equality or rule by law, i.e. producing norms addressed to a type, class or category of people performing certain actions with many individual tokens, and thus avoid formulating 'individual norms': not doing so would amount to legislation through decrees, not laws. In the words of John Austin, when a command "obliges generally to act or forbearances of a class, a command is a law or rule" (Austin 2007, 38).

Therefore, arbitrary law-making of the illegal type can occur in two different ways. First, it may originate in a lack of respect for the given constitutional limits to the formulation of the law. Second, it can express itself through decrees inspired by contingent interests, stretching these beyond "reasonableness". This meaning of arbitrary law-making is similar to the kind of behaviour and norms issued by what Ernest Fraenkel labelled the "prerogative state" as opposed to the "normative state", governed by the rule of law. In the prerogative state, the ruler "acts not only independently of the law but, if necessary, in opposition to it" (Fraenkel 2006, 67).

In the first subtype of arbitrary law-making as illegal practice, we find lawmaking that observes the formal, procedural requirements of law-making within a given constitutional framework (e.g. the procedural rules of Parliament for enactment of laws), yet does not live up to substantial constitutional limits regarding the content of the law (the example par excellence is fundamental rights). In the second subtype of arbitrary law-making we find law-making that instead fails to live up to formal, procedural standards of law-making within a given constitutional framework (e.g. ruling by decree during a crisis).

The second type of arbitrary law-making is the exercise of a power that has exceeded the limits set by law, by opting for an irrational choice. It is this idea of arbitrary law-making that Timothy Endicott (2014) is thinking of when he defines arbitrariness as "lack of reason". Irrational here means at odds with the standards of logic or the means-to-an-end calculus. The form of rationality that is implied here is Zweckrationalität, i.e. that which is instrumentally rational in the sense of Max Weber $(1978,25)$. This is perhaps the most common way that we understand 
'arbitrary law-making', where 'arbitrary' is cast as synonymous with 'ungrounded' or 'unjustified' from the point of view of instrumental rationality, i.e. inconsistent or otherwise incapable of reaching its own goals.

This type of arbitrary law-making, referring to irrational policies, finds a classical topos in Leibniz's theory of justice (1988). In asking whether "justice is arbitrary" Leibniz identifies two possible opposed views: on the one hand, there is the view associated with Thomas Hobbes, according to which justice is grounded only upon the will of the sovereign and the strength to enforce it; on the other hand, there is Leibniz's own conception of universal reason (ratio) as a limit to the sovereign's particular will (voluntas). For Leibniz, the legitimacy of a decision should be based on a rational demonstration of its moral correctness, to prevent political choices being made that are influenced by the interests or particularistic aims of the rulers. Leibniz's conception of arbitrariness is perhaps the classical conception most closely linked to the contemporary analytical understanding of 'arbitrary', as that which is morally unjustified (see section 3.1.). As such, however, Leibniz's notion is hard to employ within the legal setting (for the reasons given in the same section); it is best placed within the Natural law tradition from which it stems. Yet, we need not commit ourselves to any such theory of the nature of law. It is sufficient to adopt a deflated view of what rationality requires.

Hence, arbitrary law-making can be said to be of the irrational kind if it is internally inconsistent (at odds with the logical requirement of consistency) or suffers from inadequacy between the declared goals and the means deployed to reach these. This deflated view of the requirements of rationality is sufficient to highlight practices that appear to be irrational from the viewpoint of the recipients of the law (ex parte populi), albeit not necessarily from the viewpoint of the legislators (ex parte principis). The recipients or addressees of the law may face Kafkaesque situations, that are unintended consequences of law-makers' choices.

The third type of arbitrary law-making is the exercise of a power that exceeds the limits set by law, by opting for discriminatory choices. An authority can be said to exercise power in discriminatory ways in (at least) two senses: It can violate the principle of equality "before the law" (égalité devant la loi) or it can violate the principle of equality "within the law" (égalité dans la loi). The two paradigmatic cases embodying these two options are (1) unequal treatment of two citizens motivated by the partiality of the court and (2) parliament passing discriminatory bills. Here we consider only the second meaning, since adjudication is not the object of this paper. Even since Justinian's corpus iuris civilis first gave the principle of justice its canonical formulation in our legal systems, égalité dans la loi has been understood to relate to the very conception of the institutional facts that ground the law: on this understanding, the 'equals' are those members of a set to be treated identically, "with respect to their equality" (Aristotle, E.N. V), i.e. in so far as they have a determinate quality that the other members of the set share. Conversely, the 'unequals' to be treated unequally or non-identically 'with respect to their inequality' refer to members of different sets that, as such, do not share identical qualities across sets (e.g. one is to treat thieves and murderers differently).

One way in which discrimination occurs is of course through practices that are discriminatory according to the law. However, this would constitute an illegal practice and is not the type of arbitrary law-making that is referred to here. Indeed, the law prohibits certain discriminatory behaviours, and nonobservance of this 
prohibition challenges the rule that bans the behaviour in question. It is quite another matter when law-makers' choose to read discrimination into the statuses of the law. Behaviours that embed discrimination into the law are not strictly speaking illegal, though they may be profoundly unjust. Discriminatory statuses are based on categories that in themselves challenge the basic equality principle of legal systems. This feature is what makes them unjust. Non-positivists may see discriminatory statuses as jeopardising legality tout court, yet where a distinction is maintained between illegality and injustice, discriminatory statuses jeopardise the principle of equality and not legality as such.

This said, it is still the case that discriminatory statuses endanger the basic principle of justice, which prescribes treating equals equally and unequals unequally. Discrimination, in fact, is not just any form of non-identical treatment; it is unequal treatment of the kind based on particular and unjustified reasons, as in the case of the parent who punishes only one of two children, guilty of the same fault, because the child is less dear to him (Hart 2002, 185).

This type of arbitrary law-making, in reference to discriminatory statuses, finds a classical topos in the debate over the 'reasonableness of the law' (Perelman 1978, Aarnio 1987, MacCormick 1999 \& 2005, Atienza 2007, Bongiovanni, Sartor and Valentini 2009). Unreasonable law refers to cases where a difference of treatment in the law is insufficiently justified, in absence of reasons that in turn would justify giving no motivation (Cohen 2015). Unjustified reasons may creep into the law when law-makers institute different legal consequences on the basis of characteristics that are irrelevant for a given action class. Consider for instance that, before the revolt of the suffragettes, gender differences between men and women were held to constitute a reason not to enfranchise women. These same features are now considered irrelevant for the action class of enfranchisement, yet are still held to be relevant for other action classes (e.g. gender features are held to constitute sufficient reason for differentiated parental leave in many countries).

A law can thus be considered unreasonable - i.e. constitute discrimination, and thus be arbitrary - if two (or more) people are treated differently without there being "sufficient reasons" for making a difference between them. A typical way in which the lack of sufficient reason manifests itself is by referring to certain features that are irrelevant for determining whether or not the individual has the ability to enjoy or exercise the rights and obligations deriving from the status to be attributed. Strictly speaking, "arbitrary" qualifies the acts of the authority that creates a discriminating (i.e. insufficiently motivated) status in the law. A bill that for example would treat brown-haired thieves differently from fair-haired ones would be arbitrary in that the naturalistic feature - hair colour - is not reason enough to justify differentiated legal treatment when it comes to punishing thieves, even though other naturalistic features - like cognitive abilities - might be relevant (e.g. for extenuating circumstances).

The limits of the power to construe categories of 'equals' are of course always debated in practice, although such disagreement does not constitute an objection against the distinction in principle. At the heart of the problem of discrimination lies the question of whether a factor relevant in one situation is also relevant in another situation, rather than determining which factors are relevant for a given decision-making situation (Lippert-Rasmussen 2014; Khaitan 2015). Unreasonable or discriminatory rules could hence be said to be arbitrary in two different ways. 
These two ways form two subtypes of arbitrary law-making of the third kind. On the one hand, unreasonable rules are arbitrary in this third sense because they protect the particular interests of those who derive their preferential or privileged treatment from the existence of group discrimination; on the other hand, unreasonable rules are arbitrary in this third sense because their justification is based on refutable arguments.

Finally, it is worth stressing that the typology canvassed may also be of interest for adjudication practices. From the perspective of legal reasoning, one needs to distinguish between being confronted with an irrational or non-sensical provision (e.g. to command $a$ and non- $a$ at the same time), an "illegal" provision that can be overruled by a higher court and a discriminatory provision which may be debatable on the basis of substantial principles in a legal system, yet still requires further qualification to be distinct from legitimate use of discretion.

It is noteworthy that much good research done in contemporary legal philosophy on vagueness and legal indeterminacy has hitherto not been systematically connected to studies of arbitrary power in political philosophy. Yet there are reasons to think unlimited powers may be inclined to make a broader use of discretion in law-making than other forms of authority would be. After all, as Cardinal Richelieu (1641) famously pointed out, "if one would give me six lines written by the hand of the most honest man, I would find something in them to have him hanged." Whether unlimited power is likely to lead to a broader use of discretion in law-making than other forms of authority remains an open empirical question. Mindful of such further developments, the purpose of the rest of the paper is not to tease out what each form of arbitrariness could imply for adjudication practices. Rather, it is dedicated to stressing the value of the typology in relation to the field of migration and citizenship policy. This is warranted because legal theorists who have worked on the reasonableness of the law - like Perelman, MacCormick or Alexy - have not explored how arbitrariness appears in this policy field.

Once we have acknowledged the undertheorised distinction between arbitrariness and discretion, and between various modes of expression of arbitrary power, it is easier to see how a legitimate power may, in stretching its legitimate use of discretion, fall into a categorically different type of law-making: arbitrary lawmaking. The multitude of ways in which this crossing the line occurs remain to be explored in relation to the policy area that we now turn to.

\section{Arbitrariness as Illegality}

The aforementioned typology may help us distinguish different forms of abuse in the areas of citizenship and migration policy. Let us start by examining the first kind of arbitrary law-making.

The clearest form of arbitrary use of power in relation to citizenship policy and border control is the state or its agencies acting in breach of the law. There are evidently numerous cases of illegal conduct by states, but an egregious contemporary form of arbitrary law-making in migration law consists in ad hoc design of jurisdiction.

The Tampa Affair that led Australia to take the unprecedented action of rendering part of its territory unapt to receive asylum requests illustrates this type 
of breach. Early in August 2001, a group of asylum seekers, mostly Afghans fleeing the Taliban regime, boarded a barely seaworthy vessel in southern Indonesia. The Norwegian Tampa rescued them as their vessel was sinking off the coast of Christmas Island, Australia. When the Tampa sought to disembark on the island, the Australian government took the exceptional step of closing its territorial seas in order to prevent them from claiming asylum. Troops boarded the ship by stealth to deliver food and medical assistance. The Australian government succeeded in preventing the asylum seekers from entering Australian territory. In the so-called "Pacific solution", Australia entered an agreement with New Zealand, Papua New Guinea and Nauru to accept those on board and rendered parts of Australian territory "non-territory" for the purpose of claiming asylum (Rubenstein 2002, 102). Now, "to maintain sovereignty for the purposes of, say, asserting resource rights in the Timor Sea, but not for purposes of receiving asylum applicants, is not something contemplated by international law" (Dauvergne 2021, 58). Since the Tampa affair, ad hoc design or re-management of jurisdictions has been regularly practised by states in order to obtain a variety of border control effects.

Another popular violation of international law by liberal-democratic states is refoulement en mer, practised by several states, including Italy around the international waters surrounding the isle of Lampedusa, in violation inter alia of Art. 3 of the European Convention for the Protection of Human Rights and Fundamental Freedoms ('ECHR') and Art. $10 \$ 3$ of the Italian Constitution. This has led to the condemnation of the Italian practices by the Strasbourg Court, which has stressed the absolute nature of the obligation of non-refoulement (Saadic. Italie, ECHR 28/02/2008).

A perhaps less obvious form of arbitrariness in terms of illegality is offered by the very category of "illegal migrants." What exactly is an illegal person? Other terms are often used as equivalent, such as unauthorised, undocumented, clandestine, irregular and more. In the paradigm of the modern rule of law, persons cannot in themselves be illegal; only actions, not status, can be deemed illegal, by virtue of the principle of personal responsibility. In English, "illegal" as an adjective that qualifies an action or omission has now become a noun that qualifies people. It is worth recalling that in the mid-twentieth century "the noun 'illegal' was used in reference to Jewish migrants in various places" (Dauvergne 2012, 10). The noun also implies the assumption that these people be regarded as criminal in a mala in se sense. The category of "illegals" stands for what John Searle called an "institutional fact" (Searle 1995). It is a creation of the law, not a feature of the world (Mindus 2020). "Just as a physicist calibrates her instruments differently to find a wave or a particle, state migration agencies will find illegal migration when they set out to look for it" (Dauvergne 2012: 15). Consider the fact that you may not have acted your way into illegality - you may have been born into it. Your parents might have failed to register the birth of their children.

A person may also fall in and out of illegality according to updates in a country's migration law, and not as a consequence of individual action. This is of some importance, in particular since there has been a global crackdown on illegal migration starting in the 1990s. The crackdown has led to a series of effects, such as the "discovery" of an increasing "illegal population" that happens to be so categorised following the very changes in the law that made them appear. "Illegal migration" has been understood as an unconstitutional category, to be rejected on 
the basis of lex superior derogat, since it is aimed at people and not at acts, which is inconsistent with the principle of personal responsibility (Ferrajoli 2011). For instance, minors who are children of individuals entering the territory illegally are deemed illegal yet cannot be held accountable for illicit action or omission since they lack full legal capacity. Also of note is that a large proportion of the undocumented population never actually crosses a geographical border illegally, but instead crosses temporal borders by simply overstaying their visas (Cohen 2020). Given that the law can obscure time and reverse time, overstayers may be unaware of the time limits they are subjected to (Bailey 2009, Simmelink 2011, IneliCiger 2017). Such experiences include temporary forms of protection or residence that last decades or, as in the case of UAE, are turned into permanent legal status. This is then codified into formal citizenship status by outsourcing passports from the Union of Comoros, thus allowing the state to effectively reclassify minorities into foreign residents (Lori 2019). More could, and perhaps should, be said on the assessment of free choice and responsibility when it comes to unlawful presence in the territory; here it is enough to stress that no necessary conceptual link exists between unlawful presence and choosing to cross the border, and this suffices to call for a reconsideration of the category of illegal migrants against the backdrop of the principle of personal responsibility. The very notion of 'illegal migrants' can thus be listed as a practice of arbitrary law-making applied to the field of migration policy, where "arbitrary" stands for "in breach of constitutional and international law".

\section{Arbitrariness as Irrationality}

A set of policies relating to citizenship and border control can offer examples of arbitrariness as irrationality. Many Kafkaesque situations arise from the administrative procedures to which foreigners are subjected (Gargiulo 2017). Here we only give a few examples pertaining to the instrumental sense of incoherence as a mismatch between means and ends (i.e. inconsistency). The state sometimes uses blunt instruments to select whom to keep and whom not to keep. Some policies therefore appear irrational or inconsistent from the point of view of the applicant, who is often subjected to incomprehensible administrative practices, and not from the point of view of the law enforcement agencies.

The so-called Safe Third Country Rules are an example of one such case. These rules stipulate that if asylum seekers pass through a safe country in transit to the country in which they claim asylum, they can be returned to the safe country. Safe Third Country Rules have become very popular in the EU. Germany, for example, revised its constitution in 1993 to exclude from its constitutional right to asylum anyone 'who enters the federal territory from a Member-State of the EU or from another third state.' The first concern of German immigration officials is to ascertain asylum seekers' travel itineraries in order to determine their eligibility to file an application. The Dublin Convention treats all EU members as safe third countries, including transit states in Eastern Europe. "Because the core asylum countries in Northern and Western Europe are surrounded by 'safe' countries, it is very difficult for an asylum seeker to initiate an asylum claim at a land border of any of these states" (Price 2009: 211). The irrationality stems from the fact that it does not make sense to have an asylum regulation that admits people arriving by 
land if the land way access is effectively barred from being used for the purpose of presenting an asylum request.

Another striking feature of arbitrary rule in citizenship policy is the situation of many illegal residents (sans-papiers already present on the territory) who turn out to be de facto stateless because "many governments place high demands upon the return of nationals who have destroyed their identity documents in order to evade repatriation" (Ellerman 2009: 14), and "immigration officials often cannot procure travel documents if diplomatic relations between the two governments are highly hostile or nonexistent" (Ellerman 2009: 25). This means that many such people effectively end up in a legal limbo, producing incoherence in the law. They cannot stay, but they may not go. A case that made headlines illustrating this kind of untenable situation was that of Ruiz Zambrano, a Columbian national, "illegally resident" in Belgium since his asylum application was refused in 2000. Such a rejection, however, did not entail deportation: the notification order issued to him and his family included a non-refoulement clause stating that they should not be sent back to Colombia in view of the civil war in the country. Having minor children who had acquired Belgian nationality (because Belgian nationality is automatically given to individuals born in the country who would otherwise be stateless, and Columbian law does not recognise children born outside its territory) and having had for many years an ordinary employment contract, when Ruiz Zambrano lost his job and applied for unemployment benefits, he discovered that the Belgian National Employment Office refused to grant him the benefits, because he lacked a work permit that could be issued only to individuals enjoying the right of residence. This case was resolved by an intervention of higher law. The Tribunal du travail de Bruxelles in Belgium, decided in 2008 to refer to the European Court of Justice for a preliminary ruling. The case concerned inter alia the interpretation of fundamental rights in the EU, since the ECHR bans the deportation of children having the nationality of the state in question. Deporting the father, an illegal third country national, would de facto amount to depriving those children of the genuine enjoyment of the rights of EU citizens. In many cases, however, possibilities to call for the intervention of higher law are not given.

Moreover, these absurd situations are not reserved only for asylum seekers but for other migrants as well, including Italian citizens previously resident in South America who returned to their country of nationality. A citizenship-related example of such arbitrary law-making is a consequence of the Italian Bossi-Fini law:

The police stations argued that granting a work permit during the process of naturalisation was a violation of the 'Bossi-Fini' provision, because it formally introduced non-EU workers into the labour market beyond the quotas that had been established. However, these conflicts often ended with agreements of convenience based on common sense: people who have been granted a permit of stay for up to a year cannot be prohibited from working without eventually creating the conditions for public unrest. Quite reasonable, except that the decision taken by the Ministry of Home Affairs, in December 2006, adopted the strict legalistic interpretation given by some police stations, creating a 'Kafka-like' situation. According to the Italian government, the residents waiting for citizenship recognition ex iure sanguinis were Italian by birth and during the process of attesting their alleged citizenship status, they were granted a period of legal residence in the country on much more 
favourable terms than other non-EU citizens. However, then the privilege consists only in legal residence, which paradoxically does not entitle the person to access the labour market, where he or she continues to be considered a non-EU citizen (Tintori 2009: 64).

The irrationality here lies in the contradiction between the legal fiction implied in enjoying the entitlement of nationality ex iure sanguinis and still not being able to access the labour market legally in your "own" country.

In this category of "irrational" naturalisation requirements we should perhaps also list the naturalisation policy to become a Cypriote. The country has a relatively liberal policy for naturalising (seven years of residence and other minor requirements) but only extends permits of stay for four years for working purposes, making naturalisation a de facto option only for rentiers.

Finally, arbitrary measures of the irrational type are those that have contradictory effects or appear to be irrational from a consequentialist standpoint: consider the fact that safe country lists also enable so-called chain deportation. "For example, in 2003 Germany regarded the Czech Republic as safe, the Czech Republic regarded Slovakia as safe, and Slovakia regarded Zimbabwe as safe! Slovakia also returned Chechen asylum seekers to Ukraine, which in turn has deported them back to the Russian Federation" (Price 2009, 221). The irrationality appears when the whole chain is taken into account.

Other impracticable measures are also in current use with the purpose to curtail the possibility for people to present asylum requests. One such case involves excessive limitations applied to filing deadlines. While the US deadline is very generous (within 12 months after entering the country), some other cases stand out as being nonsensical: for instance, until 2000, Slovakia had a 24-hour deadline and Bulgaria a 72-hour deadline. "In Slovakia the clock began ticking when asylum seekers first entered the country, even if only to pass through en route to a destination further West. If they were to return from their destination (...) they would have discovered that they had already missed the filing deadline (...). Moreover, rejected applicants further have only a very brief window within which appeals can be filed - as of at least 2000, in Germany, manifestly unfounded applicants had three days to appeal; in Belgium such port-of-entry applicants detained close to the port had only one day to appeal" (Price 2009: 212-13). What often renders such filing deadlines impossible to respect is that the appeal process requires gathering cumbersome and sometimes unattainable corroborative evidence. The burden of proving that corroborative evidence requested by the adjudicator is not available is often placed on the applicant.

A more recent example of policy that can be labelled arbitrary as irrational concerns the application of the principle of non-refoulement in the wake of the rapid spread of the COVID-19 virus worldwide. The legal implications of the current health emergency include measures to curtail the possibility of accessing territory and presenting asylum requests. Many states have adopted restrictive measures to limit free movement within their territories and across their borders. On 20 March 2020, the US Centers for Disease Control and Prevention, issued an order that suspended the entry of persons travelling from Canada or Mexico who require processing at the borders, regardless of their country of provenance. Many EU Member States have declared the state of emergency or exception to limit the entry of all non-nationals, pursuant to the EU Travel Ban put in place on 16 March 
2020. Only Bulgaria, Ireland, Luxembourg, and Romania expressly clarified that persons in need of international protection or applying for protection for other humanitarian reasons are able to enter into the territory; the Netherlands, Portugal and Spain also allow entry but with restrictions (Carrera \& Chun Luk 2020: Annex II). Italy, for one, closed its ports on 7 April 2020 pursuant to the view that

for the entire period of health emergency resulting from the spread of the COVID-19 virus, Italian ports will lack the necessary requirements to be classified a 'Place of Safety' under the definition of the Hamburg Convention on search and maritime rescue, for cases of rescue carried out by naval units flying a foreign flag outside the Italian SAR [Search and Rescue] area (Carrera \& Chun Luk 2020: Annex II).

It is clear that coastal States like Italy are bound by customary international customary law to rescue people in distress at sea. The principle of nonrefoulement does not allow derogations. States may not choose to avoid fulfilling the requirements for being considered 'places of safety' for asylum seekers in order to avoid the positive obligations deriving from the principle of non-refoulement, namely the right to an effective asylum procedure, in the name of the current health emergency. Denying disembarkation or entry to the territory does not prevent spread of the virus if migrants are doomed to stay in potentially overcrowded camps at international borders or in a protracted situation of distress at sea. Such conditions are likely to worsen the precarious health conditions of the individuals concerned. There is no evidence suggesting that denying disembarkation would significantly help the national health system, especially not in Italy where disembarkation typically occurs in the southern regions, which are relatively unaffected by the pandemic. Emergency health measures can be enforced without jeopardising the non-refoulement principle by, for instance, imposing isolation or quarantine. Alternative solutions to denial of entry clearly exist. This example illustrates the bluntness of the tool employed, as well as its irrationality: it does not lead to a reduction in the number of infected individuals. As such, it is a case of irrational policy and hence a case of arbitrary law-making.

\section{Arbitrariness as Discrimination}

In its third meaning, "arbitrary" qualifies as a form of discrimination. In the policy area under scrutiny, such arbitrary law-making can take on many forms. The policy area is, generally speaking, plagued by low or no reason-giving. The unwillingness to offer reasons is often veiled under sovereignty or national security claims, and the public is left with no real insight into why the particular choices that were made were considered preferable to alternative ways of action. But sometimes public authorities do provide reasons for their provisions. Yet, reason-giving is not the same thing as justification. Lack of justification is central to this third kind of arbitrary law-making.

This category of arbitrary law-making hinges upon unequal treatment in the meaning described above in section 3.2. In this category, the reason why the rules are discriminatory does not simply depend on a lack of reason-giving; nor on the unwillingness of public authorities to motivate the choice of a given criterion used for making a determinate distinction in the law. Here, the rules are discriminatory because they fail to consider relevant differences. Grouping individuals together 
who ought to have been treated differently - by selecting a criterion they have in common and not paying attention to the differences - can also be a way to avoid making the appropriate distinctions that a case requires. In particular, grouping people based on provenance is a strategy for obtaining this effect. Provenance allows no insight into the individual situation. Distinguishing migrants based on provenance or port of entry for the purpose of asylum application admission seems to fall into this category of arbitrary rules.

Using such a blunt instrument equals discrimination when due care is not taken to distinguish the situations of the people involved. Arbitrary rules in this policy area are, for example, when you apply for asylum in Britain. An appeal can be accepted or rejected on the grounds of your nationality:

Many states adopt presumptions against claims filed by individuals from what are deemed to be 'safe' countries of origin. In 2004, 25 countries were on Britain's 'safe' list. Countries added that year included Bangladesh, Bolivia, Brazil, Ecuador, South Africa, Sri Lanka and Ukraine (...). Rejected applicants from countries of origin deemed safe are subjected to an expedited adjudication process and have access only to non-suspensive appeals (Price 2009: 210).

This amounts to the creation of an unequal form of law. How can nationality be a reasonable ground for distinguishing between those who would benefit from an appeal and those who would not? Could it not be that one country might be deemed safe as far as risks for warfare are concerned, but not from some form of persecution? Could it not be that a certain group of people is subjected to severe risks in a "safe" country - even though most citizens are not - because of their religious beliefs, ethnic origins or sexual orientation?

Another case is the unequal treatment of refugees depending on their "port of entry". In fact, why should the geographic location of the port of entry into a country constitute sufficient reason to distinguish between two categories of refugees? Port of entry discrimination among refugees also arises in cases of "internationalisation" of ports that creates the legal fiction that asylum seekers have not actually entered the national territory. In line with the legal fiction, their removal thus does not constitute a denial of their right to apply for asylum. Like many other countries, France designated areas of its airports to be international zones' where asylum seekers can be detained without the protections normally given under French law. What naturalistic feature does the Charles de Gaulle airport have that allows it to qualify as state territory for all purposes except asylum applications?

Distinction made on religious grounds may result in discrimination that is not necessarily ideologically motivated. Drawing on archival records from a representative sample of 4000 asylum applications filed in France from 1976-2016, Mathilde Emeriau's award-winning work (2020) has provided new evidence on the determinants of asylum decisions. Linking archival records to detailed administrative data, she has shown that bureaucrats at the French asylum office initially discriminate against Muslims but stop after about a year on the job. In assessing potential mechanisms of discrimination, no support was found for the claim that discrimination is driven by bureaucrats' preferences or ideology. Rather, discrimination occurred because bureaucrats underestimate the probability that Muslims are persecuted. Muslim applicants were 30\% less likely to be granted 
asylum than Christian applicants who were otherwise similar. The discrimination was an effect of the unfounded beliefs concerning religious background and likelihood of persecution.

A more general form of "unequal treatment" emerges when no distinction is made between asylum seekers and other migrants: some policies are quite clumsy instruments, largely failing to distinguish between those who seek asylum in bad faith and those who are genuinely eligible. Such policies include reductions in the public benefits available to asylum seekers (cash transfers replaced with in-kind benefits), detention of asylum seekers, expedited proceedings, with no or minimal judicial review. Almost every country of asylum now has an accelerated decisionmaking and removal process for "manifestly unfounded" claims. One big problem with expedited removals is that those judging whether the claim is "manifestly unfounded" have no training in asylum and refugee law; for instance, they may fail to recognise that fear of domestic violence may qualify for asylum as persecution on the basis of gender.

Unequal treatment has also been noted in relation to implementation policies, an area of migration policy that is still understudied despite the so-called 'deportation turn' (Gibney 2008; Leerkes \& Van Houte 2020). For instance, there seem to be racial profiling aspects related to deportation practices in Germany, where changes in the enforcement of deportation have been made following a change in the provenance of migrants:

Comparing the typical profile of Germany's undocumented immigrants Eastern European and former Soviet nationals who entered and/or worked illegally - with those of rejected asylum seekers, many of whom originate from Asian or African countries, it is evident that the administrative efforts required for asylum removals, in particular the procurement of identity documents, far outweigh the challenge of deporting undocumented immigrants, both in terms of legal proceedings and travel arrangements (Ellerman 2009: 98).

Yet Germany deports primarily asylum seekers and not undocumented aliens. The relative neglect of undocumented immigrants by law enforcement authorities has been reflected in the absence of specific administrative infrastructures designed for their arrest and repatriation. The discriminative feature derives from overfocusing on one group vis-à-vis another.

These policies and many others embody forms of arbitrary law-making in the field of migration policy, where "arbitrary" means discriminatory.

\section{Conclusions}

Our introductory semantic analysis of the term 'arbitrary', in relation to individual or collective agency, showed that, in relation to the power or authority of one person over another, 'arbitrary' takes on axiologically negative undertones. This explains a first, rather shallow way in which one may speak of arbitrary law-making in relation to migration and citizenship policy, where arbitrary simply indicates that which is disliked. This idea of arbitrariness as a rhetorical tool for stigmatisation was found to be unhelpful for understanding arbitrary law-making. Citizenship is a 'core sovereignty' area and migration a highly-contested political issue; thus, rhetorical definitions of arbitrariness abound, yet lead nowhere. Digging a bit 
deeper, two more sophisticated understandings of arbitrariness were uncovered: a philosophical understanding, where arbitrary is synonymous with contingent and an understanding more commonly employed in legal contexts, where arbitrary is the antonym of discretion. The first of these two understandings, while useful for debating certain moral matters in normative ethics, is less well suited for debating matters relevant in migration law and policy. More appropriate for this purpose is the second of the two non-rhetorical understandings. On this basis, a typology of forms of arbitrariness was fleshed out and applied to contemporary migration policy. The policy area was here broadly construed to include not only naturalisation processes, but also migration, asylum and refugee policies and more generally border control. The typology allows us to survey arbitrariness in a variety of ways. The types of arbitrary law-making were illustrated in relation to a series of embodiments of arbitrary law-making found in contemporary citizenship and migration policies. The examples were taken from a broad range of countries and were chosen for illustrative purposes only. Other cases could exemplify the different types of arbitrary law-making that the paper elaborates. The conclusion is that we need more work on arbitrary law-making in relation to migration policy; we have taken a step in this direction by offering a basic typology of forms of arbitrariness suitable for analysing citizenship and migration policies. The paper contributed to the debate on arbitrariness in migration policy by clarifying and differentiating among forms of abuse: (a) illegal practices, (b) irrational policies and (c) discriminatory statuses. This differentiation is paramount for developing ways of understanding arbitrary law-making and reducing the arbitrary rule by public officials in migration and citizenship policies.

\section{Notes}

${ }^{1}$ The findings presented in this paper were elaborated in the research project KAW 2014.0133, sponsored by the Knut and Alice Wallenberg Foundation. I want to thank the two blind reviewers for their comments on the previous version of this paper.

${ }^{2}$ The formula is from the U.S. Supreme Court ruling Trop v. Dulles, 356 U.S. 86, 101 (1958), p. 355.

${ }^{3}$ See also Lovett 2012; for a critical perspective, Markell 2008.

${ }^{4}$ Thomas Nagel uses a slightly different meaning of moral luck from that of Williams. For Nagel, everything that escapes from the control of the subject is to be considered an object of luck. See Nagel 1993, 51-71.

${ }^{5}$ See also Freitas do Amaral 1997, 72-5; Landi and Potenza 1997, 10. For the definition of discretionary powers opposed to duty, see Debbasch 1998, de Forges 1998, 250 and Chapus 1997, 949.

${ }^{6}$ The notion of discrimination employed here is defined and discussed in Khaitan 2015. See also Somek 2011.

\section{References}

Aarnio, A. (1987). The Rational as Reasonable. A Treatise on Legal Justification. Dordrecht: D. Reidel Publishing Company. 
Alexy, R. (2009). The Reasonableness of Law. In Bongiovanni, G., Sartor, G., Valentini, C. (eds) Reasonableness and Law (pp. 2-35). Springer. https://doi.org/10.1007/978-1-4020-8500-0_1

Atienza, M. (2007). Para una razonable definición de razonable. Doxa 4: 189-200.

Austin, J. (2007). Lectures on Jurisprudence. The Lawbook Exchange.

Bader, V. (2005). Ethics of Immigration. Constellations 12(3): 331-361. https://doi.org/10.1111/j.1351-0487.2005.00420.x

Bailey, A. J. (2009). Population Geography: lifecourse matters. Progress in Human Geography 33(3), 407-418. https://doi.org/10.1177/0309132508096355

Bauböck, R. (1994). Transnational Citizenship. Elgar.

Beitz, C. (1979) Political Theory and International Relations. Princeton University Press.

Bentham, J. (1838-1843). The Works of Jeremy Bentham. Ed. Bowring, J. William Tait.

Bongiovanni, G., Sartor, G., Valentini, C. (2009). (eds) Reasonableness and Law. Springer. https://doi.org/10.1007/978-1-4020-8500-0

Carens, J. (1987). Aliens and Citizens the Case for Open Borders. Review of Politics 49 (2): 251-273.

Carrera, S., Chun Luk, N. (2020). Love thy neighbour? Coronavirus politics and their impact on EU freedoms and rule of law in the Schengen Area. Retrieved July 11, 2020, from: https://www.ceps.eu/wp-content/uploads/2020/04/LSE202004_Love-thy-neighbour.pdf

Chapus, R. (1997). Droit administratif général, Tome 1. Montchrestien.

Cohen, M. (2015). When Judges Have Reasons Not to Give Reasons. A Comparative Law Approach. Washington and Lee Law Review 72(2): 483-571.

Cohen, E. (2020). Illegal: How How America's Lawless Immigration Regime Threatens Us All. Basic Books.

Cuono, M. (2013). Decidere caso per caso. Figure del potere arbitrario. Marcial Pons.

Cuono, M. \& Mindus, P. (2018). Verso una teoria del diritto per l'età delle migrazioni di massa. Una tipologia del potere arbitrario. Rivista di Filosofia del Diritto 1:11.

Dauvergne, C. (2012). Making People Illegal. What Globalisation means for Migration and Law. Cambridge University Press.

de Forges, J.-M. (1998). Droit administrative. Presses Universitaires de France.

de Laubadère, A., Venezia, J.-C., Gaudemet, Y. (1996). Droit administratif. LGDJ.

Debbasch, Ch. (1998). Institutions et droits administratifs. Tome 2, L'action et le contrôle de l'administration. Presses Universitaires de France.

Ellermann, A. (2009). States Against Migrants. Deportation in Germany and the United States. Cambridge University Press. https://doi.org/10.1017/CBO9780511626494

Emeriau, M. (2020). Learning to be unbiased: Evidence from the French Asylum Office. Retrieved July 11, 2020, from: https://mathildeemeriau.com/files/learningtobe unbiased.pdf

Endicott, T. (2014). Arbitrariness. Legal Research Paper Series Oxford No 2/2014 January 2014. https://doi.org/10.1017/S0841820900006226

Ferrajoli, L. (2011). The Normative Paradigm of Constitutional Democracy. Res Publica 17:4, 355-367. https://doi.org/10.1007/s11158-011-9169-8 
Fine, S., Ypi L. (2016). (eds.) Migration in Political Theory. The Ethics of Movement and Membership. Oxford University Press. https://doi.org/10.1093/ acprof:oso/9780199676606.001.0001

Fraenkel, E. (2006). The Dual State. A Contribution to the Theory of Dictatorship [1941]. The Lawbook Exchange.

Freitas do Amaral, D. (1997). Curso de Direito Administrativo. Almedina.

Gargiulo, E. (2017). The limits of local citizenship: administrative borders within the Italian municipalities. Citizenship Studies 21:3, 327-343. https://doi.org/ 10.1080/13621025.2016.1277982

García de Enterría Martínez-Carande, E. (1991). ¿Es inconveniente o inutil la proclamación de la interdicción de la arbitrariedad como principio constitucional? Una nota. Revista de administración pública 124: 211-230.

Goodin, R. (1992). The Quest for Consistency. In Goodin, R., Barry, B. (eds) Free Movement (pp. 279-287). Routledge.

Gkouvas, T. \& Mindus, P. (2020) Trust in Law. In Simon, J. (ed.) Routledge Handbook of Trust and Philosophy. Routledge. https://doi.org/10.4324/9781315542294-21

Hawkins, K. (2002). (Ed.) The Uses of Discretion. Clarendon.

Hart, H.L.A. (2012). The Concept of Law. Oxford University Press. https://doi.org/ 10.1093/he/9780199644704.001.0001

Hegel, G.W.F. (2010). Encyclopedia of the Philosophical Sciences. Cambridge University Press.

Igartua, J. (1996). Discrecionalidad, arbitrariedad y control judicial. RVAP 46:95.

Ineli-Ciger, M. (2017). Temporary Protection in Law and Practice. Brill Nijhoff. https://doi.org/10.1163/9789004327535

Jones, C. (2001). Global Justice. Oxford University Press. https://doi.org/10.1093/ gmo/9781561592630.article.20622

Juss, S. (2006). International Migration and Global Justice. Routledge.

Khaitan, T. (2015). A Theory of Discrimination Law. Oxford University Press. https://doi.org/10.1093/acprof:oso/9780199656967.001.0001

Landi, G., Potenza, G. (1997). Manuale di diritto amministrativo. Giuffrè.

Leerkes, A. \& Van Houte, M. (2020) Beyond the deportation regime: differential state interests and capacities in dealing with (non-) deportability in Europe. Citizenship Studies 24:3, 319-338. https://doi.org/10.1080/13621025.2020. 1718349

Leibholz, G. (1959). Die Gleichheit vor dem Gesetz. Beck.

Leibniz, G.W. (1988). Meditation on the Common Concept of Justice [1702-03]. In Leibniz, G.W. Political Writings, ed. Riley, P. Cambridge University Press. https://doi.org/10.1017/CBO9780511810084

Lifante Vidal, I. (2003). Dos conceptos de discrecionalidad jurídica. Doxa 25: 413. https://doi.org/10.14198/DOXA2002.25.12

Lippert-Rasmussen, K. (2014). Born Free and Equal?: A Philosophical Inquiry into the Nature of Discrimination. Oxford University Press. https://doi.org/ 10.1093/acprof:oso/9780199796113.001.0001

Locke, J. (1982) Two Treatises on Government. Arlington Heights.

Lori, N. (2019). Offshore Citizens: Permanent Temporary Status in the Gulf. Cambridge University Press. https://doi.org/10.1017/9781108632560 
Lovett, F. (2012). What counts as arbitrary power? Journal of Political Power 5: 1, 137-152. https://doi.org/10.1080/2158379X.2012.660026

Lovett, F. \& Pettit, P. (2009). Neorepublicanism: A Normative and Institutional Research Program Annual Review of Political Science 12:1, 11-29. https://doi.org/10.1146/annurev.polisci.12.040907.120952

MacCormick, N. (2005). Rhetoric and the Rule of Law . Oxford University Press. https://doi.org/10.1093/acprof:oso/9780199571246.001.0001

MacCormick, N. (1999). Reasonableness and Objectivity. Notre Dame Law Review 74:5, 1575-1586.

Markell, P. (2008). The Insufficiency of Non-Domination. Political Theory 36: 1, 936. https://doi.org/10.1177/0090591707310084

Mesquina, J. (2003). El concepto de discrecionalidad y su control. Anales de la Cátedra Francisco Suárez 37: 337.

Mindus, P. (2020). Om vissa juridiska föreställningars sanning. Svensk Juristtidning. 2020:1.

Mindus, P., Spaak T. (2021) (Eds.) Cambridge Companion to Legal Positivism. Cambridge University Press (forthcoming).

Mindus, P. (2019). Hacia una teoría funcionalista de la ciudadanía. Marcial Pons.

Mindus, P. (2017). European Citizenship after Brexit: Freedom of Movement and Rights of Residence. Palgrave. https://doi.org/10.1007/978-3-319-51774-2

Mindus, P., Prats, E. (2020). (Eds) Special issue on Migration and Legislation. Theory \& Prac. Legis. 7: 2, 73-84. https://doi.org/10.1080/20508840.2020.1729554

Montesquieu, C.L.S. (1989). The Spirit of the Laws [1748] Cambridge University Press.

Moore, M. (2017). A Political Theory of Territory. Oxford University Press.

Nagel, T. (1993). Moral Luck. In Statman, D. (ed.). Moral Luck (pp. 51-71). State University of New York Press.

Nardin, T., Mapel, D. (1992). Convergence and Divergence in Internationational Ethics. In Nardin, T., Mapel, D. (eds.) Traditions of International Ethics (pp. 297-322). Cambridge University Press. https://doi.org/10.1017/ CBO9780511521768

Nine, C. (2012). Global Justice and Territory. Oxford University Press.

Ochoa Espejo, P. (2016). Taking Place Seriously: Territorial Presence and the Rights of Immigrants, The Journal of Political Philosophy. 24: 1, 67-87. https://doi.org/10.1093/acprof:oso/9780199580217.001.0001

Ochoa Espejo, P. (2020). On Borders: Territories, Legitimacy and the Rights of Place. Oxford University Press. https://doi.org/10.1093/oso/9780190074197. 001.0001

Perelman, C. (1978). Le raisonable et le déraisonable en droit. Sirey.

Plato (1903). Platonis Opera. Ed. John Burnet. Oxford University Press.

Price, M.E. (2009). Rethinking Asylum. History, Purpose and Limits. Cambridge University Press. https://doi.org/10.1017/CBO9780511626845

Ragonesi, V. (1996). Manuale di diritto amministrativo. Il Sole 24 Ore Norme e Tributi.

Ramón Fernández, T. (1998). De la arbitrariedad del legislador: una crítica de la jurisprudencia constitucional. Civitas.

Ramón Fernández, T. (2008). De la arbitrariedad de la administración. Civitas. 
Ramón Fernández, T. (2016). Arbitrario, arbitraire, arbitrary: pasado y presente de un adjetivo imprescindible en el discurso jurídico. Iustel.

Rebelo de Sousa, M., Salgado de Matos, A. (2008). Direito Administrativo Geral. Dom Quixote.

Rubenstein, K. (2002). Citizenship, Sovereignty and Migration: Australia's Exclusive Approach to Membership of the Community. Public Law Review 13: $102 \mathrm{ff}$.

Rothstein, B. (2011). The Quality of Government: Corruption, Social Trust, and Inequality in International Perspective. University of Chicago Press. https://doi.org/10.7208/chicago/9780226729589.001.0001

Shachar, A. (2009). The Birth Right Lottery. Harvard University Press. https://doi.org/10.2307/j.ctvjhzr8r

Shapiro, S. (2011). Legality. Harvard University Press. https://doi.org/10.2307/ j.ctvjnrsd5

Searle, J. (1995). The Construction of Social Reality. The Free Press.

Simmelink, J. (2011). Temporary Citizens: U.S. Immigration Law and Liberian Refugees. Journal of Immigrant \& Refugee Studies 9:4, 327-344. https://doi.org/10.1080/15562948.2011.616793

Somek, A. (2011). Engineering Equality. An Essay on European Anti-Discrimination Law. Oxford University Press. https://doi.org/10.1093/acprof:oso/ 9780199693375.001 .0001

Spaak, T. (2003). Norms that confer competence. Ratio Iuris 16: 1. https://doi.org/10.1111/1467-9337.00225

Spinoza, B. (2000). Political Treatise [1676]. Hackett.

Tintori, G. (2009). Fardelli d'Italia? Conseguenze nazionali e transnazionali delle politiche di cittadinanza italiane. Carocci.

Wacks, R. (2017). Introduction to Jurisprudence. Oxford University Press.

Walzer, M. (1983). Spheres of Justice. Basic Books.

Weber, M. (1978). Economy and Society. University of California Press.

Williams, B. (1981). Moral Luck. Cambridge University Press. https://doi.org/ 10.1017/CBO9781139165860 